\title{
GAY CLOWNS, PIGS AND TRAITORS: AN EMOTION ANALYSIS OF ONLINE HATE SPEECH DIRECTED AT THE SWEDISH- SPEAKING POPULATION IN FINLAND
}

\author{
Karin Sandell \\ PhD Student in Nordic Folkloristics, Abo Akademi University, Finland \\ Researcher for the Committee for Ethnology and Folkloristics \\ Society of Swedish Literature in Finland \\ e-mail: karin.sandell@abo.fi
}

\begin{abstract}
The article deals with the emotion analysis of online hate speech, studying the way that emotions are performed in online hate speech directed at the Swedish-speaking population in Finland. The material originates from the public debate forum Suomi24. In analysing the forum posts, I intend to show how hatemongers use emotional words, emotive expressions and metaphors referring to the Finnish national awakening and how this is connected to the populist discourse of today. As a result, three categories of hate speech emerge from the material: suspicion, demasculinization, and dehumanization.
\end{abstract}

Keywords: dehumanization, demasculinization, emotions, Finland, online hate speech, performativity, populism, suspicion, the Swedish-speaking population in Finland

\section{INTRODUCTION}

Gay clowns, pigs and traitors to the country - these are representations of three different categories of online hate speech directed at the Swedish-speaking population in Finland. The hate speech is exceedingly emotive and sprinkled with metaphors referring to nineteenth-century Finland.

The debate climate in Finland has become harsher and more populist in nature during the last years. Hatemongers, who one might picture lurking in the darker corners of the Internet, have stepped into the public debate, often anonymously, but also more and more frequently with their full name and picture. Unlike traditional trolls, they do not burst when exposed to light, rather they bask in the spotlight growling about their right to speak their mind in the name of free speech (Yle 2015; Pöyhtäri \& Haara \& Raittila 2013: 39-43). 
Over 90 percent of the Finns are of the opinion that deliberate provocation has increased in public debate, and more than half are so tired of the aggressive climate that they consider withdrawing completely from the debate (Pitkänen \& Westinen 2016: 6). The toughening of the debate climate coincides with increased support for the right-wing populist Finns Party, which in turn is part of the rise of populist radical right parties with anti-immigration agendas throughout Europe (Sakki \& Pettersson 2015; Jungar \& Jupskås 2014; Lähdesmäki \& Saresma 2014: 300). Along with the tougher debate climate, the occurrence of hate speech in Finland has increased during the recent years. According to a survey among the targeted groups, ${ }^{1}$ hostile speech and conduct have become more and more acceptable, while the will to resolve the problem has not increased. Minorities in Finland most often encounter harassment in public places and, secondly, on the Internet. The respondents have been verbally insulted, called names, shouted at, physically threatened or spat on. A majority of the respondents have been harassed up to ten times during the past year because they belong to a minority group (MoJ 2016).

About 5.5 percent of the Finnish population is Swedish-speaking and is one of the minority groups subjected to hate speech, both online and offline. In this article, I am focusing on online hate speech aimed at the Swedish-speaking population in Finland. Please note that I do not indicate that the majority of the Finnish-speakers partake in the hate speech directed at the Swedish-speaking population or any other group (Saukkonen 2011: 88-89).

Online hate speech is generally defined as hostile remarks directed at individuals and/or groups in the form of articles, comments, e-mails, blog posts and various discussions on the Internet.

[T]he term 'hate speech' shall be understood as covering all forms of expression which spread, incite, promote or justify racial hatred, xenophobia, anti-Semitism or other forms of hatred based on intolerance, including: intolerance expressed by aggressive nationalism and ethnocentrism, discrimination and hostility against minorities, migrants and people of immigrant origin. (Council of Europe 1997)

This recommendation, made by the Council of Europe's Committee of Ministers, applies particularly to hate speech spread through media, but does not define what kind of media. When using the terms 'hate speech' or 'online hate speech', I will be referring to the kind of hate-mongering that takes place on the Internet, if not stated otherwise.

According to folklorist Trevor Blank, the efficiency and anonymity of the Internet makes it an ideal channel for the transmission of folk narratives. The anonymity makes people more daring; instead of using circumlocution, they 
express their views more aggressively (Blank 2009: 9). Journalism scholar Melissa Wall compares the comment field to a virtual town hall, an open meeting on the Internet where the commentators have the possibility to be anonymous (Wall 2005: 163). Internet comments are often meant to be insignificant and not to be taken seriously, but one should remember that comments that remain online and open for everyone to see also have an influence on the public debate at large (Skogerbø \& Winsvold 2008: 41-43). The Internet is often looked upon as a democratic arena where everyone and anyone can have their say, but as journalist and author Lisa Bjurwald, among others, has pointed out, the users tend to read only what already confirms their view of the world (Bjurwald 2013). As noted by philosopher Martha C. Nussbaum, emotions such as disgust and envy can cause great damage, for instance when disgust is seen as a valid reason to discriminate against a group of people, especially if relied upon as guides in society and in the legislative process (Nussbaum 2013: 3). According to Reeta Pöyhtäri, Paula Haara, and Pentti Raittila at the Research Centre for Journalism, Media and Communication at the University of Tampere, aggressive speech may lead to a reduced variety of opinions due to an emotional atmosphere of hate and fear. They also call into question whether freedom of speech could be limited and to what extent, in case that freedom is used to offend and threaten people (Pöyhtäri \& Haara \& Raittila 2013). Øyvind Strømmen, journalist and author, has researched right-wing extremist online environments and analysed the ideologies behind Anders Behring Breivik's acts of terrorism. ${ }^{2}$ Strømmen's research shows a connection between online hate speech and the very tangible consequences it might have (Strømmen 2012).

The aim of this article ${ }^{3}$ is to study how emotions are performed in online hate speech directed at the Swedish-speaking population in Finland. The starting point of my analysis is the method for emotion analysis through figures of speech developed by Sara Ahmed, professor in Race and Cultural Studies, in The Cultural Politics of Emotion (2004) and utilized by Lena Marander-Eklund, professor of Nordic Folkloristics, in her article on the emotion analysis of postwar memories (2009). I will apply the method to material consisting of textual examples of online hate speech directed at the Swedish-speaking population. I intend to show how the hate speech of today - online - is connected to expressions of hatred in the past. 


\section{WHAT EMOTIONS DO}

The theoretical approach for this article is to view online hate speech as performative. Performativity, here defined as the performative capacity of speech and communication, turns the attention to what action the statement performs or consummates, not to the linguistic meaning (Butler 1993). I will examine how emotions are performed in the material by analysing the quotes, focusing on emotional words, emotive expressions and metaphors.

Emotions are performative and expressing them makes them 'real' (Ahmed 2004: 13). I align myself with Ahmed, who argues that our emotions toward an object originate from cultural conceptions. According to her, emotions are not something we have for an object; they are created in the encounter with the object (Ahmed 2004: 7). In other words, emotions are produced in the interaction between self and society, material settings, cultural symbols and so on, and are not simply shaped by interpersonal relations (Riis \& Woodhead 2010: 7). The researcher should therefore examine what emotions do, instead of asking what emotions are (Ahmed 2004: 7). Ahmed is critical of the model where emotions are regarded as psychological states. Instead, she introduces the sociality of emotion in terms of a model in which emotions are regarded as social and cultural practices. Ahmed names the psychological model of emotion the 'inside out' model of emotions; according to this model, a person has feelings that move outward towards objects and other people, and these feelings might return to the person in whom they originated (Ahmed 2004: 8-9). She changes the direction and suggests that feelings 'come from without and move inward' (Ahmed 2004: 9). She exemplifies this with the feeling of grief felt by a whole nation that was mourning the death of Princess Diana. This feeling of grief could be understood as existing in the crowd and having been taken in by individuals. Ahmed herself criticizes the 'outside in' model because it also, just as the 'inside out' model, considers emotions as something 'we have', and in the case of Diana's death, the crowd becomes the one who 'has feelings' (Ahmed 2004: 9-10). Taking this into consideration, Ahmed presents her sociality of emotion model in a way that rejects the idea that emotions are something ' $\mathrm{I}$ ' or 'we' have. 'Rather, it is through emotions ... that surfaces or boundaries are made: the "I" and the "we" are shaped by, and even take the shape of, contact with others' (Ahmed 2004: 10). Emotions, Ahmed suggests, circulate and move, but they also become attached. 'Movement may affect different others differently ... emotions may involve "being moved" for some precisely by fixing others as "having" certain characteristics' (Ahmed 2004: 11).

According to Ahmed, emotions can be studied through figures of speech that are necessary for the emotionality of the text (Ahmed 2004: 11-13). In order to 
analyse emotions in texts, she proposes focusing on figures of speech, such as metaphors. Ahmed views metaphors as a means of conveying emotions (ibid.). A metaphor is a manner of talking about an entity by experiencing and understanding it via something else (Lakoff \& Johnson 2003: 5).

Marander-Eklund utilizes Ahmed's method with a few additions in her article on memories from the 1950s Finland. While Ahmed suggests focusing on emotional words and metaphors, Marander-Eklund adds a third category to the emotion analysis - words with emotive character, or emotive expressions. This third category of emotional communication is necessary since emotions are not always clearly expressed through the process of naming them or through metaphor in her material on post-war memories. I have made the same observation regarding my web forum material. In order to analyse the material using the emotive expression, I focus on the use of emotionally charged words, whether the words are neutral or intense, positive or negative. For instance, words such as wonderful and brilliant are positive, while miserable and arrogant are negative - and all four of them are intense. Emotive expressions are expressive in character and the opposite of matter-of-fact statements (Marander-Eklund 2009: 25).

The named emotions, such as 'hate', rarely occur in my material, an aspect that I will discuss further in the analysis chapter. Ahmed argues that the naming of an emotion makes the emotion 'real', resulting in different kinds of actions and orientations (Ahmed 2004: 13). Metaphor and emotive expressions work in a similar fashion. Emotive expressions are words with emotive character, which are used to convince the reader or listener. An emotive expression can also be used to express a particular emotion or attitude and/or to provoke a particular emotion or attitude (Hedquist 1978: 1). An emotive expression does not name an emotion but may allude to the writer's own feelings about something or try to influence the intended recipient's feelings. As noted by Marander-Eklund, this is a wide definition that also encompasses the effect of emotive expressions on the reader or listener (Marander-Eklund 2009: 25). This, of course, includes me as a researcher and a Swedish-speaking Finn.

In Marander-Eklund's article from 2009, the material consists of answers to a questionnaire in which the respondents were specifically asked to write about life in Finland during the 1950s. My material for this article is palpably different, as it is created out of posts on a web forum that were not originally intended for research. The writers are also unaware of my presence as well as my intent. In Ahmed's (2004) material, on the other hand, I find that there are some similarities to mine. She analyses public material from websites hosted by the British National Front, a right-wing populist party, and the American white supremacist organization Aryan Nation. Whereas the content of Ahmed's 
material is similar to mine, the setting is different. My material originates from a more 'neutral' and diverse source, a debate forum that is open to various topics. Hence, I will examine whether Ahmed's and Marander-Eklund's methods and theories are applicable to web forum material.

\section{SWEDISH IN FINLAND}

Finland and Sweden share a common history, which is why Finland has a population of Swedish speakers. Finland was a part of Sweden for over 600 years, until 1809, when Finland became an autonomous part of the Russian Empire. Swedish and Russian ${ }^{4}$ served as official languages in Finland until 1863, when Finnish was made an official language, along with Swedish, by the tsar. To wean the Finns from their Swedish influences, the Russians encouraged them to develop cultural, political, and financial institutions and traditions of their own (Coleman 2010: 47). Consequently, the idea of an independent Finnish nation began to evolve. Language was an essential part of the nation-building process and both Finnish and Swedish speakers argued Finland should become monolingually Finnish in order to build a unified nation (Coleman 2010: 49). Swedish speaker Adolf Ivar Arwidsson is quoted as saying, 'Swedes we are no longer, Russians we cannot become; we must be Finns' (Coleman 2010: 49; McRae \& Helander \& Luoma 1997: 32). This served as a guiding principle of Finnish nationalism (ibid.).

From the 1840s, the Finnish national movement, the Fennoman movement, comprised of the political and cultural elite in Finland - both Finnish and Swedish speakers - worked to make Finnish a language of culture and science, arguing for the teaching of Finnish national history in schools, thus elevating the Finnish language from its former status as a language of the peasantry (Coleman 2010: 49). Although the Finnish peasantry itself hardly showed any interest in national or cultural matters, it was a movement driven by a very small elite (Honko 1980: 47-48). The Fennomans published much of their work in the Finnish language, spreading their ideas to both language groups. As a reaction to this, the Swedish national movement, the Svecoman movement, arose to uphold the elite position of the Swedish language (Coleman 2010: 49). The late nineteenth and beginning of the twentieth centuries were dominated by language disputes. In 1945, in concurrence with the end of the war with the Soviet Union, peace was made between the languages, much due to the radical changes in Finland's social and political situation (McRae \& Helander \& Luoma 1997: 80-81). 
Earlier, a large part of the upper classes had been dominated by Swedish speakers, but since the beginning of the twentieth century, this social divide has faded. However, one may describe Swedish speakers as a predominantly middle-class population (Allardt \& Starck 1981: 182). Nonetheless, the notion of the Swedish-speaking upper class persists both in the vernacular and popular culture. Swedish speakers are referred to as 'better people', upper-class, snobs, et cetera (Klinkmann 2014: 121-122; Heikkilä 2011).

Finland declared its independence in 1917. The Constitution of Finland, written in 1919, states that the nation has two languages, Finnish and Swedish. Today, Finland has a population of 5.5 million. Slightly over five percent of the population is registered as being Swedish-speaking (Statistics 2017a, 2017b). The teaching of Swedish is mandatory in Finnish-speaking schools and vice versa. The teaching of Swedish in Finnish-speaking schools, however, is continuously up for political debate. ${ }^{5}$ In its wake follows an often spiteful debate about the Swedish-speaking population and the Swedish language in Finland.

Hate speech directed at the Swedish-speaking population in Finland is not a new phenomenon, just as hate speech in general existed long before the Internet; see, for example, Bo Almqvist on insult poetry in the Nordic countries (1965), Lars M. Andersson on representations of 'the Jew' in Swedish comic press around 1900-1930 (2000) and Erik Falk's thesis Verbal Insults in Uppsala [Sweden] during the 1630s (2011). The difference, today, is the possibility to reach a much bigger audience than you might by scribbling on a wall or shouting in the streets.

In Finland, hate speech is not directed only toward the Swedish-speaking population. It also targets, for example, various ethnic groups (the Sami, Romani people, Russians, and Somalis, to mention a few), immigrants, asylum seekers, politicians, journalists, researchers, and women (Lähdesmäki \& Saresma 2014: 300-301; Pöyhtäri \& Haara \& Raittila 2013: 33-43). According to the survey report entitled 'I often find myself thinking how I should be or where I shouldn't go' - Survey on hate speech and harassment and their influence on different minority groups, published by the Finnish Ministry of Justice, Unit for Democracy, Language Affairs and Fundamental Rights in 2016, representatives of minority groups are more exposed to harassment and hate speech than those of the majority population. As noted by Tuuli Lähdesmäki and Tuija Saresma (2014), among others, there is a connection between the recent rise of populism and nationalism in Finnish politics and the increase of online hate speech. 


\section{WEB FORUM MATERIAL}

The material used in this article consists of quotes from the public web forum at Suomi24. The commercial website Suomi24. $\mathrm{f}^{6}$ is one of the largest social networking sites in Finland with 3.5 million visits per week, according to their own statistics from $2015^{7}$. Besides the discussion forum, the site provides, for example, a dating forum, an e-mail service and chat rooms. The discussion forum is divided into several groups with topics like hobbies, travelling, economy, sports, family, and society. These groups are then divided into subgroups like the society discussion group, from which most of my material originates, with subtopics like animal protection, conspiracy theories, the European Union, feminism, history, immigration, media, and politics. These subgroups are divided into even more specific subjects. For example, under politics, one can find topics such as government, parties, and the president, which are then further divided into smaller groups, and so on. On Suomi24, no registration is required and anyone can write a text and publish it as a new post, or write a comment to a post or another comment. Therefore, one main post may consist of several discussion threads.

The material presented in this article originates primarily from September 2015, when I searched for evident examples of online hate speech directed at the Swedish-speaking population in Finland. I started out searching for forum posts with the word 'hurri' (a common pejorative used for the Swedish speakers in Finland and for the Swedes in Sweden) through the site's own search engine. Other findings are the result of associations I made while browsing the listed forum threads. For example, words like 'sveco' (short for Svecoman, see section "Dehumanisation"), 'RKP' (Ruotsalainen kansanpuolue: The Swedish People's Party of Finland), names of Swedish-speaking politicians and other Swedish-speaking public figures made me examine the content of the discussions more closely.

The forum posts used in this article date back to April 2015. Most of the forum posts were published around the time when I did most of my searches, the 8 th of May 2015, and the 9th and 10th of September 2015. The exact dates are found together with the quotes in the analysis. I decided not to look for more material from a longer period of time for this article because I think this also shows that one does not have to dig very deep to find this particular kind of hate speech. My search for material in the web forum also came to a point where I noticed that the content of the posts started to repeat itself and I decided my material had reached saturation. The quotes presented in this article act as representatives of several other quotes on the same theme. Although my material consists of 14 separate main posts, the linked comments increased the 
total to 25 posts. The original quotes are in Finnish. ${ }^{8}$ According to Suomi24's own rules, the two official languages on the site are Finnish and Swedish, but most of the content on the site is in Finnish (Suomi24 2016). Most of the forum posts are still available online, but a handful of them have been deleted by the administrators without any further explanation.

I have not been in contact with the forum administrators or with the debaters. As mentioned before, the material is published in an open web forum accessible to anyone and requiring no registration. The participants in the debate forum change their signature depending on the discussion topic. In my material, all 25 posts have different signatures and they are not linked to any e-mail addresses or sites. I have, therefore, decided, after a brief discussion with the university research ethics committee, that informed consent is not needed (cf. Markham \& Buchanan 2012).

As stated above, the original quotes are in Finnish and the ones presented in this article are translated into English by an authorised translator. There is, of course, still a risk of misinterpretation and a loss of nuances. To weed out as many errors as possible, I have made an in-depth evaluation of both the original and the translation in my analysis.

\section{REAL FINNISH MEN AND DECEITFUL WOMEN}

My material contains the three categories presented by Ahmed (2004) and Marander-Eklund (2009): emotional words, metaphors, and emotive expressions. Just as Marander-Eklund notes in her article, the presence of actual emotional words is sparse. Out of my 25 quotes, I have found only a couple of examples of an emotion actually being named (see Post $1 \& 4$ ). On the other hand, the use of metaphor as well as emotive expressions is frequent. Concerning emotive expressions, I argue that the majority of my material might qualify as being emotive in the sense that the writer uses certain words to express and/or to provoke a certain emotion or attitude. Hence, I choose not to analyse the material solely based on this categorization. During my reading of the texts through emotive expression, emotional words, and metaphors, three themes surfaced: suspicion, demasculinization and dehumanization. In the following passage, I will present examples of all three different types and make a contextual and in-depth analysis of the textual content. 


\section{Suspicion}

Suspicion is based on sentiments and stereotypes; a suspicious person is not to be trusted. Casting suspicion upon a group can become an instrument for discrimination disguised as a self-protective strategy. For example, as Juliana Ochs shows in her ethnographical study of everyday life in Israel, Israelis use the term 'suspicious people' as a euphemism for Palestinian or 'Arab-looking' people. Naming them 'suspicious people' depicts their fear of Palestinians as a question of security rather than discrimination (Ochs 2011: 82).

Suspicion is used here as a category for material containing examples of hate speech that casts suspicion upon the Swedish-speaking population. The material shows expressions of general distrust towards the Swedish-speaking population in Finland, and it is conveyed by questioning whether the Swedishspeakers see themselves as a part of the Finnish population or as Swedes.

Insolence seems to be something that the Hurri-shitheads inherited from their Swedish ancestors. Here in Finland, you are the most hated group because of your arrogance towards the main population. Note that the main population comprises 95 percent of the people in Finland and you, a Swedish group of shits or Hurri-shitheads, are only a measly 5 percent. (Post 1)

The word Hurri requires further explanation, as it is used in the majority of the comments. There are several etymological theories regarding the origins of the word Hurri. According to language expert Mikael Reuter it has been a well-known pejorative for Swedish speakers in Finland at least since the beginning of the twentieth century. Reuter argues that mongers were called Hurri in several Finnish dialects and, furthermore, that the word has been used as a euphemism for 'wolf' (Reuter 1999). Today it is commonly used as a pejorative for the Swedish-speaking population as a whole. However, Hurri is not always understood in a negative sense in all contexts. It can also be used by the Swedish-speakers themselves, mostly as a form of self-irony (Klinkmann 2014: 125). In this particular context, however, I argue that it is used as a word of abuse. In this example, the negative connotation is accentuated by the addition of the word 'shitheads'. Furthermore, using words such as shithead or other terms alluding to faecal matter is common when talking about an opposing group (Lindqvist 2001: 206). A word such as Hurri cannot be detached from its history as a pejorative, despite its other usages and interpretations; in Ahmed's words, it tends to stick (Ahmed 2004: 59-60, 89ff.). In this article, Hurri is considered a negatively charged metaphor for the Swedish-speaking population in Finland. 
The word 'hated' in the quote above is one of the aforementioned rare examples of an emotional word found in my material. Marander-Eklund made a similar observation in her article on post-war memories (2009: 35-36). Her interpretation is that the informants wrote about things that happened decades ago and this may have led to some reconstructions of the memories. Regarding examples of online hate speech in the material used in this analysis, I argue that the writers are more likely to use emotive expressions and metaphors because obviously emotional arguments are not accepted as easily as stated 'facts'. However, the writers cannot fully conceal their emotions and attitudes, thus resulting in more or less emotional statements (cf. Mral 2013: 107; Walton 1992).

Looking at Post 1 as a whole, one notices that the writer is excluding the 'you', the Swedish speakers, from 'the main population' by using the pejoratives Hurri and 'shithead', and is stating that the Swedish speakers are descendants of Swedes and, therefore, inherently arrogant. In naming an emotion, such as hate, Ahmed argues that a feeling does exist before the utterance, but the effect of naming it makes it 'real' and, as a result, it shapes 'different kinds of actions and orientations' (Ahmed 2004: 13). The implied 'we' in this quote distances itself from the arrogant Swedish-speaking shitheads. By mentioning the main population's large numerous advantage, I also sense an underlying threat. The Swedish speakers are made aware of their disadvantage in relation to the Finnish speakers.

The quote highlights the notion of Swedish speakers as arrogant, a group who sees themselves as better than the Finnish speakers. By juxtaposing the 'main population' and the 'Swedish group', the writer emphasizes the Swedish speakers' position as outsiders. In addition, the word Swedish (ruotsalainen in the original quote) is used instead of a Swedish-speaking Finn (suomenruotsalainen in the original quote) to further stress that the group in question is not Finnish.

The claim that the Swedish speakers are the most hated group in Finland is a very strong statement. The statement also raises the question of which other groups are hated, although not as much as the Swedish speakers. Arrogance toward the Finnish speakers is stated as the reason for this hate, which makes me question whether being arrogant really is this despicable, or does this socalled arrogance imply something else? What does it mean to be arrogant? The Oxford English Dictionary explains arrogance as follows:

The taking of too much upon oneself as one's right; the assertion of unwarrantable claims in respect of one's own importance; undue assumption of dignity, authority, or knowledge; aggressive conceit, presumption, or haughtiness. (OED 2016a) 
Considering this definition in this particular context, the Swedish speakers' arrogance could imply that they see themselves as superior to the Finnish speakers and, therefore, act badly towards them (cf. Saukkonen 2011: 92-93). The notion of the Swedish speakers' arrogance dates back to the nineteenth century, when Swedish was the only official language in Finland. Marja Vuorinen has pointed out that the Swedish nobleman was made to represent the enemy from the old empire by the Fennoman movement in the nineteenth century. The Finnish-speaking intelligentsia viewed the nobility as remnants of the Swedish rule and, therefore, something the people must distance themselves from in order to build a democratic nation (Vuorinen 2005: 249-250). Johan Wilhelm Snellman (1806-1881) formulated the ideas of the Fennoman movement. Language was a central part of Snellman's thesis on how to develop the country, and he saw the language as a reflection of the nation's own unique way of thinking. Therefore, he felt that Finland should become monolingually Finnish (Lindgren, A. \& Lindgren, K. \& Saari 2011: 21). Anna-Riitta Lindgren, Klaus Lindgren, and Mirja Saari describe the 1800s as 'the century of assimilation politics', an era when nationalism with its ideas of monolingual nation states spread through Europe (Lindgren, A. \& Lindgren, K. \& Saari 2011: 24).

According to Vuorinen, the hatred toward the Swedish-speaking population in Finland was linked to the hatred toward the upper classes. The fact that there were Swedish speakers among the common people was ignored by the Fennomans. Rather, the Finnish nationalists willingly quoted the racial theories emerging in Sweden, according to which Swedes were large, lively and hard-working Germans, while the Finns were melancholic, untalented and slow descendants of Siberian Ugric tribes, unable to build a nation of their own. These views strengthened the idea of the Swedish speakers as being hateful and considering themselves to be superior to the Finnish speakers (Vuorinen 2005: 259-260). By labelling somebody as hateful, they become objects of hate, which in turn corroborates our impression of them as hateful (Ahmed 2004: 52). By labelling Swedish speakers as arrogant, the hatred toward them is vindicated, because they are hateful.

The suspicion of Swedish speakers as a group is shown through questions inquiring whether they want to be a part of the Finnish nation or not.

Hurri Fantasy number 1. Why do some Hurris want Finland to come under Sweden's rule again? (Post 2)

Hideous traitors to the country. (Post 2.2)

Row back to Sweden, Hurris, just like you fled during the war. (Post 3) ${ }^{9}$ 
Post 2 claims the Hurris are fantasizing about Finland coming 'under Sweden's rule again'. By not writing, for instance, 'become a part of Sweden again', which is a common view on the shared history of the two nations (cf. Klinge 2000 [1981]; McRae \& Helander \& Luoma 1997: 26-27), the quote is connected to the occupation discourse, according to which Finland was occupied by Sweden but not an equally integrated part of the kingdom ${ }^{10}$ (Vilkko 2014: 225-228). Post 2.2 answers the question posed in Post 2: Swedish speakers 'want Finland to come under Sweden's rule again' because they are 'hideous traitors to the country'. Post 3 expresses the same view on the Swedish speakers as traitors not to be trusted, by suggesting they 'row back' to Sweden like they 'fled during the war'.

'Row back' is a thought-provoking metaphor considering it is actually possible to row a boat from Finland to Sweden over the Gulf of Bothnia. Furthermore, the sea has been, and still is, important for the communication between the two countries. Today, during the ongoing migrant crisis, people are migrating to Europe by boat, ${ }^{11}$ and we are exposed to pictures of these migrants almost daily. Post 3 was published at the time when the amount of asylum seekers started to increase noticeably in Finland. ${ }^{12}$ The discourse about fleeing the war and consequently your duty to fight for your country is similar to the ones expressed in the posts quoted above. While Syrian men are accused of fleeing instead of fighting, ${ }^{13}$ the Swedish speakers in Finland are blamed for not having fought for Finland during the wars in 1939-1945. ${ }^{14}$ However, it is an incorrect statement to claim that the Swedish speakers in Finland fled the war; there were, for example, several monolingually Swedish infantry regiments (Juutilainen 1997). A film based on the experiences of the Swedish-speaking soldiers in the 61st Infantry Regiment, entitled Beyond the Front Line, reached large audiences nationally (Strandén 2010: 127). Therefore, I argue that the claim is a metaphor for the Swedish-speaking population's untrustworthiness; the Swedish speakers cannot be trusted as citizens of Finland.

Suspicion is expressed in these quotes through metaphors that imply that Swedish speakers are spineless quislings. Emotive expressions are used to illustrate both the writer's own views and to convince the other debaters of the Swedish-speaking population's untrustworthiness.

\section{Demasculinisation}

Demasculinization is, in this work, perceived as a strategy to strip the Swedishspeaking men of their gender-related authority (cf. Ferber 2000: 45-48). I argue that this authority and male privilege is connected to the notion of hegemonic masculinity, where certain masculinities are more dominant and encouraged 
than others in society. Hegemonic masculinity is not necessarily the most common pattern of masculinity in a society, but is produced through certain exemplars of masculinity, such as professional athletes, symbols of authority, even though most men and boys do not manage to completely live up to them (Connell $\&$ Messerschmidt 2005: 846). In this section, I will analyse a quote in which Swedish-speaking men, in both Finland and Sweden, are considered unmanly since they are not characterised by the hegemonic masculinity represented by the Finnish-speaking men in Finland.

Oh my, the Hurri 'men' are jealous of us 'Fennos', us real Finns, we who are real men and not slick, gay-looking clowns - like the Håkans. Hurri 'men' are like Swedish men, feminist wimps who are being laughed at. (Post 4)

The author of Post 4 prides himself on being a 'real man' and a 'real Finn' and hence, a part of the hegemonic masculinity, while the Swedish-speaking men in Finland are not fulfilling the demands of the hegemony.

The word 'men', with quotation marks added to emphasise the ironic tone, is being used as a metaphor for men who do not fulfil the demands of hegemonic masculinity. '[M]en' are the opposite of real men. 'Fennos' is a metaphor, which is clarified in the quote as meaning real Finns, real men, and the definition of a real Finn and a real man is explained through the contrast between 'the Hurri "men" and 'Swedish men'. While the quotation marks are added around the word 'men' for ironic emphasis, 'Fennos' should be read as so-called Fennos, the quotation marks indicating the writer might not be sure if the use of the word is entirely correct in this context. ${ }^{15}$ The quote states the "men" are 'jealous' of the 'real men'. Jealous is an emotional word that implies that Swedish-speaking men are envious of Finnish-speaking men because of their so-called real manliness. The idea of an allegedly real or true Finnish masculinity is analysed by folklorist Mikael Sarelin in his dissertation on constructions of masculinities within Finnish Black Metal music. According to Sarelin, the real Finnish man is the opposite of the so-called metrosexual man, a man who cares about his looks and soft values, someone who might be considered as having feminine qualities (Sarelin 2012: 162-164). Feminine characteristics are associated with homosexual men who are subordinate to the hegemonic masculinity - hence the Hurri men and Swedish men are inferior to the 'real men' in Finland (Connell \& Messerschmidt 2005: 837). Lars M. Andersson uses the national body as a term for the ideal masculinity presented by the Swedish men (in Sweden) in contrast to the Jewish man's unmanly body. Andersson argues that the ideas of masculinity and nationality overlap to a great extent (Andersson 2000: 120-126). The similarities in terms of how the Swedish-speaking men are depicted are striking; Swedish-speaking men are unmanly 'slick gay-looking clowns', Jewish 
men are pictured as cuckolds, physically weak and, therefore, unfit as soldiers and possibly homosexual (ibid.). 'Looking gay' is not accepted by the hegemonic masculinity and being a clown is being laughed at. The clown is a metaphor for someone being ludicrous, laughable, and not to be taken seriously. Clown, pelle in the original quote, also translates into fool or buffoon in Finnish, which may be linked to the idea of the emasculated Swedish-speaking man (Lindqvist 2001: 218-220).

'The Håkans' (håkanit in the original quote) is synonymous with using homo as a pejorative (Lindqvist 2001: 218-219). Håkan is a common Swedish male name and contains the letter 'å' (capital ' $\AA$ '), which is not commonly used in the Finnish language. " $\AA$ " is a letter in the Swedish alphabet and in Finnish it is only used in names or words of Swedish or foreign origin (Häkkinen 2005: 83). As noted by Yrsa Lindqvist, it is common to label an opposing group as being deviant. In this case, Finnish speakers have labelled (male) Swedish speakers as homosexuals. Homosexuality is, here, perceived as something unnatural, unwanted, and foreign to Finnish norms. The link between Swedish and something refined and upper class and, even further, as something feminine and effeminate, creates the notion that Swedish is the opposite of what a Finnish man is supposed to be (Sarelin 2012: 162-164; Lindqvist 2001: 218-220).

The post also refers to Swedish-speaking men as 'feminist wimps'. My interpretation of this statement is that it refers to the Swedish public discourse on feminism; Sweden is known for equality in its politics. For instance, in 2015, the Swedish government declared itself the first feminist government in the world (Government Offices 2015). Consequently, Post 4 could be read as a characterisation of the Swedish men as demasculinised - they have let the women strip them of their power by becoming feminist. As noted by Abby L. Ferber, among others, the women's movement is blamed for corrupting the natural gender order, which has led to the demasculinisation of men (Ferber 2000: 46). The Swedish-speaking men in Finland are placed in the same category as the Swedish men and, therefore, the Swedish-speaking men are just as laughable and sissy. By contrasting them to the Finnish speakers, the latter become a part of the hegemonic masculinity and the Swedish speakers are left out.

\section{Dehumanisation}

To dehumanise someone is to deprive them of human character or tributes (OED 2016b). Dehumanisation is a tool for discrimination and a pejorative term. Karen Stollznow compares dehumanisation to demonisation; both have been used by regimes, movements, and individuals to characterise an object 
as 'bad' or 'inferior' and, consequently, undeserving of equal rights (Stollznow 2008: 177-178). In the following quote, demonisation might have been just as suitable as dehumanisation; however, I find that the term dehumanisation encompasses a wider range of my material.

[Her] nickname is 'smiling death'. She talks with a soft voice and conducts herself calmly, but inside she is a fanatic Sveco-bitch. A truly RANCID Svecosuru. $\left(\right.$ Post 5) ${ }^{16}$

During my search for examples of hate speech on Suomi24, I discovered a word previously unknown to me in this particular context, namely suru. In Post 5, it is written together with sveco (short for Svecoman, more on this further down in this section). After some online research, I found that suru is short for suomenruotsalainen, which translates into Swedish-speaking Finn, and is, seemingly, mostly used in debate forums. Suru is shorter than suomenruotsalainen, hence more convenient, but suru is also the word for grief or sorrow in Finnish. Considering this and the context where it is used, I argue that it can be understood as a pejorative in the same sense as Hurri.

'Smiling death' gives frightening and negative associations. Death is a metaphor for darkness and the end of life, add a smile to that and it becomes even scarier - death in the shape of a grinning mask. What 'smiling death' denotes, is the death trying to disguise itself, making itself seem harmless - or is it a mocking smile? After reading the rest of Post 5, I interpret 'smiling death' as a metaphor for being Janus-faced, i.e., nice and calm on the outside, but deceitful inside. After some further research, I found a new forum post from 31 March 2016 with content similar to Post 5. It explains that this female politician is called 'smiling death' because she is a soft-spoken person with small gestures but an extremely fanatic Svecosuru (Post 6). There are records of both Finnish speakers and Swedish speakers comparing each other to the devil, which may be interpreted as associating the unknown, something not like us, with evil (Lindqvist 2001: 210-211). Naming someone 'smiling death' and Svecosuru are examples of dehumanisation; it deprives the person of her humanity.

Stating that in reality, 'inside', she is a 'fanatic Sveco-bitch' can be understood as her hiding the fact that she is an extreme Swedish nationalist - a Svecoman. The Swedish national movement arose in the mid-1800s as a reaction to the Finnish national movement, the Fennomans. The Swedish speakers turned to the teachings of Axel Olof Freudenthal, who opposed Snellman's ideas to make Finland monolingually Finnish (Högnäs 1995: 52-54). Freudenthal was highly regarded by the Svecomans, as were his views on the Swedish speakers in Finland as guardians of the west against the barbarians in the east. As noted by Vuorinen, this highly resembles the Finnish speakers' attitude towards the Russians (Vuorinen 2005: 259-260). 
As a 'truly RANCID Svecosuru', she is so extremely nationalist it reeks. Through the use of strong adjectives such as fanatic and rancid, the commenters' hatred toward her is strengthened. The composition of sveco and suru further amplifies the emotionality of the post, depicting a person who is not just a Swedish speaker but a nationalist fighting for the rights of the Swedishspeaking population, in an aggressive but furtive manner. She is, therefore, not to be trusted since she hides her true intentions.

'Sveco-bitch' is a metaphor used to convince the reader that she actually is like a Sveco-bitch (cf. Saarikoski 2001: 130). Bitch, narttu in the original quote in Finnish, a word I argue is closer to its original meaning, female dog ${ }^{17}$, than the word bitch ${ }^{18}$ in English. The word bitch (in English) is also used in Finnish. The Finnish online urban dictionary also makes a distinction between narttu and bitch, narttu being a very crude nickname for a woman and also meaning female dog, while a bitch is an argumentative, stubborn, and sometimes slutty woman. Furthermore, bitch is a word used by women as a pejorative for other women (US a, US b). Therefore, I argue that the word narttu (translated to bitch in Post 5) is an example of dehumanisation, an even stronger example than bitch. Naming someone a narttu or a bitch is depriving her of her human traits and labelling her an animal with strong sexual implications. Closely associated to bitch, whore is a metaphor for a woman who is not a proper or real woman - she is like a whore (Falk 2011: 193-194; Saarikoski 2001: 131). Stating she is a bitch emphasises her being female and, even more so, a lewd woman. A man naming a woman a bitch is a show of power, because there is no equivalent pejorative for men (Saarikoski 2001: 87). According to Lindqvist, a common trait in narratives about an opposing group is an allusion to sexuality, or a comparison to animals or excrement (Lindqvist 2001: 206). Bitch encompasses both sexuality and a comparison to animals.

The female politician referred to in the quote above is a woman with political power; she is a part of the Swedish-speaking population and a well-known public figure. Calling her a bitch because she is a woman is exercising oppression. In Post 5, she is made to represent the Swedish-speaking population as a whole and is, therefore, seen as a threat to be warded off. A bitch may bark but will never be accepted by the male hegemony.

Another example of how dehumanisation is used as a strategy by the hatemongers is the following post in answer to Post 2, which asks why the Swedish speakers 'want Finland to come under Sweden's rule'.

Because they are pigs. (Post 2.1)

The Swedish speakers are named pigs. Pig is a metaphor for a dirty animal but also someone who is greedy and lazy. If you eat like a pig, you have bad table manners; a capitalist pig exploits others and only cares about making more 
money; if you are pig-headed you are stubborn and refuse to listen to anyone else. All of the above are found in the discourse about the Swedish-speaking population, for example, in terms of the upper classes exploiting the common people and the ongoing debate about the mandatory teaching of Swedish in Finnish-speaking schools (Vuorinen 2005: 249, note 5).

With emotional words, metaphors, and emotive expressions as a point of departure, I have made a contextual and intersectional analysis with a focus on class, gender, and ethnicity. As traitors to the country, the Swedish speakers attract an extra strong hatred because they are "not a distant "other" but the enemy within' (Thiranagama \& Kelly 2012 [2010]: 2). The Swedish speakers are a group of which to be suspicious. By accusing Swedish speakers of treason, the hatemongers take it upon themselves to decide who is a part of the nation and who stands outside.

This suspicion is, furthermore, linked to the violation of norms made by the Swedish-speaking men because they do not fulfil the demands of the Finnish hegemonic masculinity and they are, therefore, depicted as demasculinised. As demasculinised men, they are nothing but a bunch of sissy wimps who no longer pose a real threat to the Finnish men, while the Swedish-speaking women are presented as a huge risk to the nation as fanatic Swedish nationalists hiding in plain sight. By dehumanising Swedish speakers, the commenters make them appear inferior and not worthy of being treated as equals to the Finnish speakers.

\section{CHARGED STATEMENTS}

The aim of this article was to study how emotions are performed in online hate speech directed at the Swedish-speaking population in Finland through the analysis of web forum posts and by using Ahmed's method with MaranderEklund's addition to the method. I have done this by focusing on emotional words, metaphors, and emotive expressions.

By analysing the selected posts, I find that emotive expressions and metaphors are used to strengthen the negative statements made about the Swedishspeaking population. As stated by Douglas Walton, '[a] weak or irrelevant argument can be taken as strong and relevant because of its powerful emotional impact on the respondent' (Walton 1992: 2), while naming emotions such as hate personalises the argument and makes it less credible and more about the arguer him- or herself (Walton 1992: 219-220). Therefore, I found that MaranderEklund's addition to Ahmed's method, the use of emotive expressions as a third category for analysing emotions in texts, was of great importance in analysing my material. Moreover, I argue that emotive expressions often include whole 
sentences or passages that together create an emotionally charged statement, while on their own, they may seem neutral.

After analysing the material, my conclusion is that the online hate speech results in and works through othering (cf. Ahmed 2004: 1-2; Sjö \& Häger 2015: 27-28). It creates an 'us' in relation to 'them'. In Ahmed's words, the expressed emotions create surfaces or boundaries between 'us' and 'them'. Emotions both circulate and stick; some people may be moved by emotion while others are branded by them (Ahmed 2004: 10-11). 'The others' are made into the enemy by describing them as arrogant and traitors to the country, and by depicting them as deviant and depriving them of their human traits. In Ahmed's words 'those who are "not us", and who in not being us, endanger what is ours' (Ahmed 2004: 1). The Swedish speakers are portrayed as a group not to be trusted and, therefore, words such as traitor, pig, and gay-looking clown are assigned to the Swedish speakers with all their implications.

\section{ACKNOWLEDGEMENTS}

This work was supported by the Committee for Ethnology and Folkloristics at the Society of Swedish Literature in Finland.

\section{NOTES}

1 The Sámi, Roma people, foreign-language speakers, foreign nationals and immigrants, disabled people, and members of religious, gender, and sexual minorities (MoJ 2016). A report on the Swedish speakers' experiences will be published later, according to the Ministry.

2 Breivik was convicted for mass murder and terrorism in Norway. On 22 July 2011, he killed eight people by detonating a bomb in the government quarter in Oslo, and then shot and killed 69 people on the island of Utøya (Townsend 2012).

3 This article is to be read as a part of my dissertation process. The working title of my thesis is Hate speech online: A folkloristic study of Internet hostility toward the Swedish-speaking population in Finland. The aim of my thesis is to study how online hate speech toward the Swedish-speaking population in Finland is made performatively. I will do this by focusing on three themes: 1) Hate speech online - when and where does it occur and how is it expressed? How is hate manifested in relation to class, ethnicity, and sex? 2) Experiences of hate speech online - how do those affected relate their experiences? 3) How do the media describe the online hate speech and the hatemongers?

4 In the late 1800 s and early 1900 s several Russification campaigns aimed to increase the use of the Russian language in Finnish government and administration and make 
the study of the Russian language and literature compulsory in Finnish schools. The Russian authorities failed to fully implement their plans. By the end of the Russian rule, merely 0.2 percent of the Finnish population was Russian-speaking (Coleman 2010: 47-48).

5 During the process of writing this article, a second citizens' initiative against the mandatory teaching of Swedish in Finnish schools was announced by the Language Choice Society (Vapaa kielivalinta ry). The initiative did not reach even half of the required 50,000 signatures within six months, and could not be submitted to the Parliament for consideration (see Initiative a, b). A previous initiative was rejected by the Parliament in March 2015 (Riksdagen 2015).

6 The site is owned by Aller Media.

7 See https://www.aller.fi/wp-content/uploads/2016/01/Suomi24-Tuotekortti-1_2016.pdf, last accessed on 19 October 2018.

8 My material is archived in the Cultura Archives at Åbo Akademi University.

9 Post 3 has been removed from the forum without any explanation as to why it was done, while posts 2 and 2.2 were still online in December 2015. Post 2.2 is posted as a comment to Post 2, while Post 3 is a separate post on the same theme.

${ }^{10}$ Sweden's part in Finnish history was debated in 2013, when the Finnish public service company Yle broadcasted the television series Suomi on ruotsalainen (Finland is Swedish). The critique was extremely aggressive and the presenter Juhani Seppänen was threatened and called a traitor to the country (Björkqvist 2013).

11 The International Organization for Migration estimates that over a million migrants arrived by sea in 2015 (IOM 2015).

12 The Ministry of the Interior published a press release on 4 September 2015 estimating that 25,000-30,000 asylum seekers would arrive in Finland by the end of the year (MoI 2015). In 2014, a total of 3,615 people sought asylum in Finland (FIS 2015).

${ }^{13}$ I do not suggest there are any further similarities between the current war in Syria and the war in Finland.

${ }^{14}$ Finland fought three wars during the Second World War: The Winter War of 19391940, the Continuation War of 1941-1944 against the Soviet Union, and the Lapland War in 1944-1945 against Germany (Lavery 2006). I assume this is 'the war' implied in Post 3 , since these are the only wars fought during Finland's independence except for the Civil War in 1918.

${ }^{15}$ Fenno is short for Fennoman, member of the Finnish nationalist movement. See Swedish in Finland.

${ }^{16}$ I have removed the name of a Swedish-speaking politician in this post. Post 5 has been removed from the forum by the administrators without any further explanation.

${ }^{17}$ Dog can also be used as a derogatory term.

${ }^{18}$ See Kleinman \& Ezzel \& Frost 2009 for an in-depth analysis of the word 'bitch' and how it has become trivialized. 


\section{ARCHIVAL SOURCES}

Cultura Archives. Åbo Akademi University, Åbo, Finland (http://web.abo.fi/arkiv/ cultura/):

Post 1: IF 2016/001, 4

Post 2: IF 2016/001, 21

Post 2.1: IF 2016/001, 23

Post 2.2: IF 2016/001, 24

Post 3: IF 2016/001, 7

Post 4: IF 2016/001, 5

Post 5: IF 2016/001, 18

Post 6: IF 2016/001, 26

\section{REFERENCES}

Ahmed, Sara 2004. The Cultural Politics of Emotion. Edinburgh: Edinburgh University Press.

Allardt, Erik \& Starck, Christian 1981. Språkgränser och samhällsstruktur: Finlandssvenskarna $i$ ett jämförande perspektiv. [Language Boundaries and Social Structure: The Finns in a Comparative Perspective.] Stockholm: Almqvist \& Wiksell Förlag.

Almqvist, Bo 1965. Norrön niddiktning : traditionshistoriska studier $i$ versmagi. Volume 1. Nid mot furstar. [Old Norse Nið Poetry: Studies in the Tradition of Verse Magic. 1. Niðð Directed against Princes.] Stockholm: Almqvist \& Wiksell.

Andersson, Lars M. 2000. En jude är en jude är en jude... representationer av "juden" $i$ svensk skämtpress omkring 1900-1930. [A Jew is a Jew is a Jew... Representations of "the Jew" in Swedish Comic Press around 1900-1930.] Lund: Nordic Academic Press.

Björkqvist, Jeanette 2013. Sveriges påverkan i Finland en känslig fråga. [Sweden's Influence in Finland Is a Delicate Question.] Svenska Dagbladet, 9 February. Available at http://www.svd.se/sveriges-paverkan-i-finland-en-kanslig-fraga, last accessed on 27 September 2018.

Bjurwald, Lisa 2013. Skrivbordskrigarna: Hur extrema krafter utnyttjar internet. [Keyboard Warriors: How Extremist Forces Use the Internet.] Stockholm: Natur \& Kultur.

Blank, Trevor J. 2009. Folklore and the Internet: Vernacular Expression in a Digital World. All USU Press Publications, Book 35. Logan: Utah State University Press. Available at http://digitalcommons.usu.edu/usupress_pubs/35, last accessed on 27 September 2018.

Butler, Judith 1993. Bodies That Matter: On the Discursive Limits of 'Sex'. New York \& London: Routledge.

Coleman, Michael C. 2010. "You Might All Be Speaking Swedish Today": Language Change in 19th-Century Finland and Ireland. Scandinavian Journal of History, Vol. 35, No. 1, pp. 44-64. http://dx.doi.org/10.1080/03468750903315215. 
Connell, Raewyn W. \& Messerschmidt, James W. 2005. Hegemonic Masculinity: Rethinking the Concept. Gender \& Society, Vol. 19, No. 6, pp. 829-859. https:// doi.org/10.1177\%2F0891243205278639.

Council of Europe 1997 = Recommendation No. R97(20) of the Committee of Ministers to Member States on 'Hate Speech'. Council of Europe, Committee of Ministers. Available at https://rm.coe.int/CoERMPublicCommonSearchServices/DisplayDCT MContent?documentId=0900001680505d5b, last accessed on 26 September 2018.

Falk, Erik 2011. Verbala förolämpningar i 1630-talets Uppsala: En historisk talaktsanalys. [Verbal Insults in Uppsala during the 1630s: A Historical Speech Act Analysis.] Uppsala: Skrifter utgivna av Institutionen för nordiska språk vid Uppsala universitet. Available at https://uu.diva-portal.org/smash/get/diva2:433855/ FULLTEXT01.pdf, last accessed on 27 September 2018.

Ferber, Abby L. 2000. Racial Warriors and Weekend Warriors: The Construction of Masculinity in Mythopoetic and White Supremacist Discourse. Men and Masculinities, Vol. 3, No. 1, pp. 30-56. http://dx.doi.org/10.1177/1097184X00003001002.

FIS $2015=$ Finnish Immigration Service. Turvapaikanhakijat 1.1.-31.12.2014. [Asylum Seekers 1.1.-31.12.2014.] Available at https://migri.fi/ documents/5202425/6161882/50498_Tp-hakijat_tammi_2014.pdf, last accessed on 27 September 2018.

Government Offices 2015 = A Feminist Government. Government Offices of Sweden. Available at http://www.government.se/government-policy/a-feministgovernment/, last accessed on 27 September 2018.

Häkkinen, Kaisa 2005. Finska. [Finnish.] In: Iben Stampe Sletten (ed.) Nordens språk med rötter och fötter. Copenhagen: Nordiska ministerrådet, pp. 75-95. Available at http://norden.diva-portal.org/smash/get/diva2:700937/FULLTEXT01.pdf, last accessed on 19 October 2018.

Hedquist, Rolf 1978. Emotivt språk: En studie i dagstidningars ledare. [Emotive Language: A Study of Newspaper Editorials.] Umeå: Umeå universitetsbibliotek.

Heikkilä, Riie 2011. Bättre folk, bättre smak? Suomenruotsalaisten maku ja kulttuuripääoma. [Better People, Better Taste? The Taste and Cultural Capital of the Swedish-Speaking Finns.] Helsinki: Unigrafia. Available at https://core. ac.uk/download/pdf/14920889.pdf, last accessed on 27 September 2018.

Högnäs, Sten 1995. Kustens och skogarnas folk: Om synen på svenskt och finskt lynne. [People of the Coast and Forests: The View on Swedish and Finnish Temperament.] Stockholm: Atlantis.

Honko, Lauri 1980. Upptäckten av folkdiktning och nationell identitet i Finland. [The Discovery of Folk Poetry and National Identity in Finland.] In: Lauri Honko (ed.) Folklore och nationsbyggande i Norden. Åbo: Nordiska institutet för folkdiktning, pp. 33-51.

Initiative $\mathrm{a}=$ Monikielinen Suomi - ruotsi valinnaiseksi. [Multilingual Finland - Optional Swedish.] Citizens' Initiatives in Finland, 4 April 2016. Available at https://www. kansalaisaloite.fi/fi/aloite/1939, last accessed 31 October 2018.

Initiative $\mathrm{b}=$ Citizens' Initiatives in Finland. Ministry of Justice, Finland. Available at https://www.kansalaisaloite.fi/sv/anvisningar/briefly_in_english, last accessed on 28 September 2018. 
IOM 2015 = International Organization for Migration. EU Migrant, Refugee Arrivals by Land and Sea Approach One Million in 2015. 18 December. Available at https://www.iom.int/news/eu-migrant-refugee-arrivals-land-and-sea-approachone-million-2015, last accessed on 27 September 2018.

Jungar, Ann-Cathrine \& Jupskås, Anders Ravik 2014. Populist Radical Right Parties in the Nordic Region: A New and Distinct Party Family? Scandinavian Political Studies, Vol. 37, No. 3, pp. 215-238. http://dx.doi.org/10.1111/1467-9477.12024.

Juutilainen, Antti 1997. Rinta rinnan: Suomenruotsalaisten joukkojen sotatiet 19391944. [Side by Side: The War Routes of the Finnish-Swedish Forces 1939-1944.] Porvoo \& Helsinki \& Juva: WSOY.

Kleinman, Sherryl \& Ezzell, Matthew B. \& Frost, Corey A. 2009. Reclaiming Critical Analysis: The Social Harms of "Bitch". Sociological Analysis, Vol. 3, No. 1, pp. 4768. Available at http://www.uet.edu.al/images/Revistat_shkencore/sociolagical/ socio3_1.pdf, last accessed on 19 October 2018.

Klinge, Matti 2000 [1981]. A Brief History of Finland. Transl. by David Mitchell and Timothy Binham. Helsinki: Otava.

Klinkmann, Sven-Erik 2014. Finlandssvenskarna och humorns gränser. [The SwedishSpeaking Finns and the Limits of Humour.] In: Lars-Eric Jönsson \& Fredrik Nilsson (eds.) Skratt som fastnar: Kulturella perspektiv på skratt och humor. Lund: Lunds Universitet, pp. 117-138. Available at http://portal.research.lu.se/ ws/files/5296797/4857084.pdf, last accessed on 27 September 2018.

Lähdesmäki, Tuuli \& Saresma, Tuija 2014. Reframing Gender Equality in Finnish Online Discussion on Immigration: Populist Articulations of Religious Minorities and Marginalized Sexualities. NORA - Nordic Journal of Feminist and Gender Research, Vol. 22, No. 4, pp. 299-313. Available at http://dx.doi.org/10.1080/080 38740.2014.953580, last accessed on 19 October 2018.

Lakoff, George \& Johnson, Mark 2003. Metaphors We Live by. Chicago \& London: University of Chicago Press.

Lavery, Jason E. 2006. The History of Finland. Westport, CT \& London: Greenwood Press. Lindgren, Anna-Riitta \& Lindgren, Klaus \& Saari, Mirja 2011. From Swedish to Finnish in the 19th Century: A Historical Case of Emancipatory Language Shift. International Journal of the Sociology of Language, Vol. 2011, No. 209, pp. 17-34. http://dx.doi.org/10.1515/ijsl.2011.019.

Lindqvist, Yrsa 2001. "Natur och kultur" - stereotypernas uttryck. ["Nature and Culture"The Expressions of Stereotypes.] In: Anna-Maria Åström \& Bo Lönnqvist \& Yrsa Lindqvist (eds.) Gränsfolkets barn: Finlandssvensk marginalitet och självhävdelse $i$ kulturanalytiskt perspektiv. Helsingfors: Svenska litteratursällskapet i Finland, pp. 206-220.

Marander-Eklund, Lena 2009. "Kanske den bästa tiden i mitt liv": Analys av emotioner i ett frågelistmaterial om livet i efterkrigstidens Finland. ["Probably the Best Time of My Life": Emotion Analysis of Questionnaire Answers About Life in PostWar Finland.] Tidskrift for kulturforskning, Vol. 8, No. 4, pp. 22-38. Available at http://ojs.novus.no/index.php/TFK/article/viewFile/449/445, last accessed on 19 October 2018. 
Markham, Annette \& Buchanan, Elizabeth 2012. Ethical Decision-Making and Internet Research: Recommendations from the AoIR Ethics Working Committee (Version 2.0). Available at http://aoir.org/reports/ethics2.pdf, last accessed on 19 October 2018.

McRae, Kenneth Douglas \& Helander, Mika \& Luoma, Sari 1997. Conflict and Compromise in Multilingual Societies: Finland. Vol. 3. Waterloo, Ont.: Wilfrid Laurier University Press.

MoI 2015 = Inrikesministern samlade en grupp för att leda asylsituationen. [Minister of the Interior Gathered a Group to Lead the Asylum Situation.] Ministry of the Interior, Finland, 4 September. Available at https://intermin.fi/sv/artikkeli/-/asset_publisher/sisaministeri-kokosi-ryhman-johtamaan-turvapaikkatilannetta, last accessed on 24 October 2018.

MoJ 2016 = Ministry of Justice, Unit for Democracy, Language Affairs and Fundamental Rights. 'I often find myself thinking how I should be or where I shouldn't go': Survey on Hate Speech and Harassment and Their Influence on Different Minority Groups. Ministry of Justice, Finland, Publications 7/2016. Available at http://justitieministeriet.fi/sv/index/julkaisut/julkaisuarkisto/1456826655763/ Files/OMSO_7_2016_VIPU-raportti_158_s.pdf, last accessed on 19 October 2018.

Mral, Brigitte 2013. Attityder som retoriska medel: Exemplet kärnavfallsfrågan. [Attitudes as Rhetorical Means: The Example of Nuclear Waste.] In: Brigitte Mral \& Orla Vigsø (eds.) Krisretorik - Retoriska aspekter på kriskommunikation. Åstorp: Retorikförlaget, pp. 105-123. Available at https://www.researchgate.net/ publication/282703745_Krisretorik_Retoriska_aspekter_pa_kriskommunikation, last accessed on 28 September 2018.

Nussbaum, Martha C. 2013. Political Emotions: Why Love Matters for Justice. Cambridge, MA: The Belknap Press of Harvard University Press.

Ochs, Juliana 2011. Security and Suspicion: An Ethnography of Everyday Life in Israel. Series: Ethnography of Political Violence. Philadelphia: University of Pennsylvania Press.

OED 2016a = Arrogance. Oxford English Dictionary. Available at http://www.oed.com/ view/Entry/11054?redirectedFrom=arrogance\#eid, last accessed on 27 September 2018.

OED 2016b = Dehumanize. Oxford English Dictionary. Available at http://www.oed.com/ view/Entry/49153?redirectedFrom=dehumanization\#eid7229816, last accessed on 27 September 2018.

Pitkänen, Ville \& Westinen, Jussi 2016. Provokaatioita ja vastakkainasetteluja kuka innostuu, kuka vetäytyy? [Provocations and Confrontations: Who Gets Excited, Who Retires?] Available at http://e2.fi/file_attachment/get/provo_net. pdf?attachment_id=30, last accessed on 19 October 2018.

Pöyhtäri, Reeta \& Haara, Paula \& Raittila, Pentti 2013. Vihapuhe sananvapautta kaventamassa. [Hate Speech Narrowing Freedom of Speech.] Tampere: Tampere University Press. Available at http://www.hssaatio.fi/wp-content/uploads/2013/11/ Vihapuhe-sananvapautta..versio_PAINOVERSIO_21.10.13.pdf, last accessed on 28 September 2018. 
Reuter, Mikael 1999. Är hurrin en hurrare? [Do the Hurri Say Hurrah?] Reuters ruta, 8/9. Institutet för de inhemska språken. Available at https://www.sprakinstitutet. fi/sv/publikationer/sprakspalter/reuters_rutor_1986_2013/1999/ar_hurrin_en_ hurrare, last accessed on 24 October 2018.

Riis, Ole \& Woodhead, Linda 2010. A Sociology of Religious Emotion. Oxford: Oxford University Press.

Riksdagen 2015 = Parliament of Finland. Riksdagens skrivelse 54/2014 rd. Medborgarinitiativ: Svenskan som valfritt läroämne på alla utbildningsstadier (MI $2 / 2014$ rd). [Citizens' Initiative: Swedish Instruction Optional in Schools.] 6 March. Available at https://www.eduskunta.fi/SV/vaski/Eduskunnanvastaus/ Documents/rsk_54+2014.pdf, last accessed on 24 October 2018.

Saarikoski, Helena 2001. Mistä on huonot tytöt tehty? [What Are Bad Girls Made Of?] Helsinki: Tammi.

Sakki, Inari \& Pettersson, Katarina 2015. Discursive Constructions of Otherness in Populist Radical Right Political Blogs. European Journal of Social Psychology, Vol. 46, No. 2, pp. 156-170. https://doi.org/10.1002/ejsp.2142.

Sarelin, Mikael 2012. Krigaren och transvestiten: Gestaltningar av mörker och maskuliniteter $i$ finländsk black metal. [The Warrior and the Transvestite: Constructions of Darkness and Masculinities within Finnish Black Metal.] Åbo: Åbo Akademis förlag. Available at https://www.doria.fi/bitstream/handle/10024/87571/sarelin_ mikael.pdf?sequence=2, last accessed on 28 September 2018.

Saukkonen, Pasi 2011. Mikä suomenruotsalaisissa ärsyttää? - Selvitys mediakeskustelusta Suomessa. [What Is Annoying About Swedish-Speaking Finns? - An Inquiry About the Media Discussion in Finland.] Helsinki: Finlands svenska tankesmedja Magma. Available at http://magma.fi/images/stories/reports/ms1101_mikasu_s. pdf, last accessed on 28 September 2018.

Sjö, Sofia \& Häger, Andreas 2015. Filmic Constructions of the (Religious) Other: Laestadians, Abnormality, and Hegemony in Contemporary Scandinavian Cinema. Temenos, Vol. 51, No. 1, pp. 25-44. Available at http://ojs.tsv.fi/index.php/temenos/ article/viewFile/9477/15570, last accessed on 27 September 2018.

Skogerbø, Eli \& Winsvold, Marte 2008. Nettet som debattarena. [Internet as an Arena for Debate.] In: Gunn Enli \& Eli Skogerbø (eds.) Digitale dilemmaer: Nye medieformer, nye utfordringer. Oslo: Gyldendal Norsk Forlag, pp. 39-60. Available at https://www.academia.edu/4717755/Digital_dilemmaer._Nye_medieformer_nye_ utfordringer_2008_, last accessed on 19 October 2018.

Statistics 2017a = Population Structure 2017: Decrease in the Number of Persons Speaking National Languages as Their Native Language Accelerated. Statistics Finland. Available at http://www.stat.fi/til/vaerak/2017/vaerak_2017_2018-03-29_tie_001_ en.html, last accessed on 17 October 2018.

Statistics 2017b = Population Structure 2017: Annual Review 2017, Appendix figure 1. Swedish-Speakers' and Foreign-Language Speakers' Proportion of the Population in 1900-2017. Statistics Finland. Available at http://www.stat.fi/til/ vaerak/2017/01/vaerak_2017_01_2018-10-01_kuv_001_en.html, last accessed on 17 October 2018. 
Stollznow, Karen 2008. Dehumanisation in Language and Thought. Journal of Language and Politics, Vol. 7, No. 2, pp. 177-200. http://dx.doi.org/10.1075/jlp.7.2.01sto.

Strandén, Sofie 2010. 'I eld, i blod, i frost, $i$ svält': Möten med veteraners, lottors och sjuksköterskors berättande om krig. ['In Blood, in Fire, in Cold, in Hunger': War Narration of Veterans, Lottas, and Nurses.] Åbo: Åbo Akademi. Available at https:// www.doria.fi/bitstream/handle/10024/66195/stranden_sofie.pdf?sequence=1, last accessed on 28 September 2018.

Strømmen, Øyvind 2012. Det mörka nätet: om högerextremism, kontrajihadism och terror $i$ Europa. [The Dark Net: On Right Wing Extremism, Counter-Jihad, and Terror in Europe.] Farsta: Molin \& Sorgenfrei.

Suomi24 2016. Suomi24:n sä̈̈nnöt. [The Rules of Suomi24.] Available at http://www. suomi24.fi/opastus/saannot, last accessed on 15 October 2018.

Thiranagama, Sharika \& Kelly, Tobias (eds.) 2012 [2010]. Traitors: Suspicion, Intimacy, and the Ethics of State-Building. Philadelphia: University of Pennsylvania Press.

Townsend, Mark 2012. Breivik Verdict: Norwegian Extremist Declared Sane and Sentenced to 21 Years. The Guardian, 24 August. Available at http://www. theguardian.com/world/2012/aug/24/breivik-verdict-sane-21-years, last accessed on 28 September 2018.

US a = Narttu. Urbaani Sanakirja. [Urban Dictionary.] Available at https://www. urbaanisanakirja.com/word/narttu, last accessed on 25 October 2018.

US b = Bitch. Urbaani Sanakirja. [Urban Dictionary.] Available at https://www. urbaanisanakirja.com/word/bitch, last accessed on 25 October 2018.

Vapaa kielivalinta. [Free Language Selection.] Available at http://vapaakielivalinta.fi, last accessed on 27 September 2018.

Vilkko, Marjo 2014. Suomi on ruotsalainen. [Finland Is Swedish.] Helsinki: Schildts \& Söderströms.

Vuorinen, Marja 2005. Herrat, hurrit ja ryssän kätyrit - suomalaisuuden vastakuvia. [Lords, Hurris, and Russian Henchmen - Finnish Counterparts.] In: Jussi Pakkasvirta \& Pasi Saukkonen (eds.) Nationalismit. Helsinki: WSOY, pp. 246264. Available at https://helda.helsinki.fi/handle/10138/166631, last accessed on 19 October 2018.

Wall, Melissa 2005. Blogs of War: Weblogs as News. Journalism: Theory, Practice and Criticism, Vol. 6, No. 2, pp. 153-172. http://dx.doi.org/10.1177/1464884905051006.

Walton, Douglas 1992. The Place of Emotion in Argument. Pennsylvania: The Pennsylvania State University Press.

Yle 2015 = Finnish MP Calls for Fight against "Nightmare of Multiculturalism", No Comment from Party Leadership. Yle News, 26 July. Available at http://yle.fi/ uutiset/finnish_mp_calls_for_fight_against_nightmare_of_multiculturalism_no_ comment_from_party_leadership/8182155, last accessed on 26 September 2018. 